\title{
Soil physical attributes in integrated bean and sheep system under nitrogen levels ${ }^{1}$
}

\author{
Atributos físicos do solo em sistema integrado de feijão e ovinos submetido a doses \\ de nitrogênio
}

\author{
Veruschka Rocha Medeiros Andreolla ${ }^{2 *}$, Aníbal de Moraes ${ }^{3}$, Andreia Kusumota Bonini $^{4}$, Leonardo Deiss ${ }^{3}$ e Itacir \\ Eloi Sandini ${ }^{5}$
}

\begin{abstract}
Integrated crop-livestock systems (ICLS) can promote higher grain and meat/milk yield as well as reduce soil degradation risks. Thus, this study aimed to evaluate the influence of grazing sheep with moderate intensity and nitrogen doses on soil physical attributes, and bean crop yield (Phaseolus vulgaris Lam.) under rotation with summer corn crop (Zea mays Lam.) and winter pasture with oats (Avena sativa Lam) and ryegrass (Lolium multiflorum Lam.) The experimental design was completely randomized blocks with split-plot; the plots were nitrogen doses and the splitplots were grazing presence or absence. The treatments were nitrogen doses of $0,75,150$ and $225 \mathrm{~kg} \mathrm{ha}^{-1}$ applied on ryegrass and white oat pasture in winter followed by bean crop. Soil density, macroporosity, microporosity and total porosity and bean grain yield were evaluated. When ICLS are managed under no-tillage with moderate grazing, sheep trampling did not affect negatively soil physical attributes, which did not reach critical levels for subsequent growth and development of the bean crop. The black bean yield in summer was not affected by antecedent presence of sheep grazing in winter.
\end{abstract}

Key words: Integrated crop-livestock system. Soil compaction. Yield.

\begin{abstract}
RESUMO - Os sistemas integrados de produção agropecuária (SIPA) podem promover maior produtividade de grãos e de carne/leite bem como reduzir os riscos de degradação do solo. Assim, o objetivo deste trabalho foi avaliar a influência do pastejo de ovinos com intensidade moderada e das doses de nitrogênio sobre atributos físicos do solo e na produtividade da cultura do feijão (Phaseolus vulgaris Lam.) em rotação com o cultivo do milho (Zea mays Lam.) e a pastagem de inverno com aveia (Avena sativa Lam.) e azevém (Lolium multiflorum Lam.). O delineamento foi em blocos ao acaso com parcelas subdivididas, sendo as parcelas doses de nitrogênio e as subparcelas a presença ou ausência de pastejo. Os tratamentos foram: as doses de nitrogênio $\left(0 ; 75 ; 150\right.$ e $\left.225 \mathrm{~kg} \mathrm{ha}^{-1}\right)$ aplicadas na pastagem de azevém e aveia branca no inverno com cultivo subsequente da cultura do feijão. Foram avaliados os atributos físicos do solo: densidade, macroporosidade, microporosidade e porosidade total, bem como a produtividade de grãos na cultura do feijão. Quando o SIPA é conduzido em plantio direto com intensidade moderada de pastejo, o pisoteio de ovinos não interfere negativamente nos atributos físicos do solo, os quais não atingem níveis críticos para o subsequente crescimento e desenvolvimento da lavoura de feijão. O rendimento do feijoeiro no verão não é afetado pela presença antecedente de ovinos na pastagem de inverno.
\end{abstract}

Palavras-chave: Sistema integrado de produção agropecuária. Compactação do solo. Produtividade.

\footnotetext{
*Autor para correspondência

${ }^{1}$ Recebido para publicação em 21/01/2014; aprovado em 28/08/2014

Extraído da TESE do primeiro autor, este trabalho foi auxiliado por bolsa de produtividade em pesquisa da CAPES

${ }^{2}$ Departamento de Fitotecnia e Fitossanitarismo, Universidade Federal do Paraná/UFPR, Rua, XV de Novembro, 1299, Centro, Curitiba-PR, Brasil, 80.060-000, vandreolla@yahoo.com.br

${ }^{3}$ Departamento de Fitotecnia e Fitossanitarismo/UFPR, Curitiba-PR, Brasil, anibalm@ ufpr.br, leonardodeiss@ hotmail.com

${ }^{4}$ Universidade Estadual do Oeste do Paraná, Cascavel-PR, Brasil, akbonini@yahoo.com.br

${ }^{5}$ Universidade Estadual do Centro-Oeste, Paraná-PR, Brasil, isandini@ hotmail.com
} 


\section{INTRODUCTION}

Integrated crop-livestock systems (ICLS) have developed significantly and shown great improvement on soil quality, environment with increased production yield (MACEDO, 2009; ANDREOLLA, 2010). In southern Brazil, ICLS have been managed as alternative to increase farmers' profitability. These systems have used plant species like black oat (Avena strigosa Schreb) and ryegrass (Lolium multiflorum Lam) integrated with a diversity of summer crops (BALBINOT JUNIOR et al., 2009).

According to Silva et al. (2011), annual pastures followed by annual grain crops become efficient the soil physical structure and chemical properties, thus, increasing plant growth, because species with different root systems and shoot morphologies promote greater nutrient cycling and can fix nitrogen from the air, leading to sustainable yields.

The animals' trampling during grazing can compact soil layers especially on moist soils and high rate of grazing stocking (GIAROLA; TORMENA; DUTRA, 2007; LANZANOVA et al., 2007). According to Conte et al. (2011) and Carassai et al. (2011), such areas can show some topsoil compaction when under moderate grazing, but it does not cause serious damage to the crop development. However, in another hand, higher grazing intensity decreases the soil cover, which can directly affect soil compaction level.

Integrated crop-livestock systems under high grazing intensity increase the soil bulk density and microporosity as well as decrease macroporosity; even though, this negative impact occurs only on topsoil. Carassai et al. (2011) and Silva et al. (2011) found out that both grazing intensity and annual cropping help on changing such compaction levels and promote a viable environment for achieving sustainable yields. Thus, ICLS are a reliable alternative because they can diversify farm environments and can associate soil-plant-animal compounds in a balanced way; therefore, they preserve and restructure the soil, increasing the organic matter and nutrients (LOSS et al., 2012).

Bean crop is a very promising alternative to be employed in ICLS, because it has a short cycle and its sowing date is easy to be managed, allowing longer periods for using pasture. Furthermore, when nitrogen is supplied to winter crops under moderate grazing stocking, it is possible to keep nitrogen residual effect for subsequent crop (REICHERT, 2012). This fact helps the maintenance of soil fertility, because it adds organic matter and facilitates the nutrients cycling (CARVALHO et al., 2010; LOSS et al., 2012).
This study aimed to evaluate how grazing and nitrogen affect the soil physical attributes and the black bean yield under summer corn and under winter oat/ryegrass in rotation with pasture.

\section{MATERIAL AND METHODS}

This experiment was carried out at the experimental area inside the Universidade Estadual do Centro-Oeste, in Guarapuava, Paraná State (PR), Brazil (51 ${ }^{\circ} 29^{\prime}$ longitude and $25^{\circ} 33^{\prime}$ latitude). Regional climate is mesothermal humid subtropical with cool summers and mild winter ( $\mathrm{Cfb}$ ), according to Köppen (MAAK, 1968), and mean annual temperature range from $18{ }^{\circ} \mathrm{C}$ to $22{ }^{\circ} \mathrm{C}$. Mean annual rainfall range from $1.400 \mathrm{~mm}$ to $1.800 \mathrm{~mm}$ and altitude is $1.100 \mathrm{~m}$ (IAPAR, 1994).

Soil is classified as Oxisol typical Distroferric (EMBRAPA, 2013). The studied area was under notillage since 2004 and the rotation was implemented (Table 1).

Table 1 - Crop rotation managements from 2004 to 2009

\begin{tabular}{lc}
\hline \multicolumn{1}{c}{ Season } & Crops \\
\hline Winter 2004 & Cereals \\
Summer 2004/2005 & Soybeans (Glycine max) \\
Winter 2005 & Fallow \\
Summer 2005/2006 & Corn for silage (Zea mays) \\
Winter 2006 & Ryegrass \\
Summer 2006/2007 & Beans \\
Winter 2007 & Ryegrass and white oats \\
Summer 2007/2008 & Corn for grains \\
Winter 2008 & Ryegrass and white oats \\
Summer 2008/2009 & Beans \\
\hline
\end{tabular}

Soil chemical analysis was carried out for undertaking a correct cropping management (Table 2). The experiment was carried out in randomized block design with split-plots and three replicates. The plots were composed by nitrogen doses while the split-plots were treatments with and without sheep grazing at moderate intensity. 
Table 2 - Chemical parameters of soil in the experimental area, Guarapuava (PR)

\begin{tabular}{|c|c|c|c|c|c|c|c|c|c|c|c|c|c|}
\hline \multirow{2}{*}{$\begin{array}{c}\text { Layer } \\
\mathrm{cm}\end{array}$} & \multirow{2}{*}{$\mathrm{pH}\left(\mathrm{CaCl}_{2}\right)$} & OM & $\mathrm{P}$ & K & $\mathrm{Ca}$ & $\mathrm{Mg}$ & $\mathrm{Al}$ & $\mathrm{H}+\mathrm{Al}$ & CEC & \multirow{2}{*}{$\frac{\mathrm{V}}{\%}$} & Sand & Silt & Clay \\
\hline & & $\mathrm{g} \mathrm{dm}^{-3}$ & $m g \mathrm{dm}^{-3}$ & & - & $---\mathrm{cmc}$ & $\mathrm{dm}^{-3}$ & & $\overline{-----}$ & & \multicolumn{3}{|c|}{--------g kg-1-------- } \\
\hline $0-5$ & 5.2 & 52.9 & 5.9 & 0.49 & 5.03 & 2.85 & 0.00 & 5.18 & 13.55 & 61.81 & 80.4 & 305.9 & 613.7 \\
\hline $5-10$ & 5.2 & 46.6 & 3.0 & 0.23 & 4.62 & 2.90 & 0.00 & 5.01 & 12.77 & 60.70 & 70.4 & 316.5 & 613.1 \\
\hline $10-15$ & & 45.9 & 2.7 & 0.21 & 4.56 & 2.84 & 0.00 & 4.73 & 12.33 & 61.59 & 76.8 & 308.0 & 615.2 \\
\hline Mean & 5.2 & 48.5 & 3.8 & 0.31 & 4.74 & 2.86 & 0.00 & 4.98 & 12.88 & 61.37 & 75.9 & 310.2 & 613.9 \\
\hline
\end{tabular}

OM: organic matter. P: phosphorus extracted by Mehlich-1 solution. CEC: cation exchange capacity at pH 7.0. V: base saturation

The total experimental area had 3.1 ha and 2.6 ha were used and divided in three blocks of 0.88 ha. Each block was divided into four plots of $0.22 \mathrm{ha}$; and inside each plot, $96 \mathrm{~m}^{2}$ area was isolated and remained without grazing. The remaining 0.5 ha was used to keep the regulator animals for maintaining the same grazing pressure among the experimental units. The treatments consisted of four nitrogen $(\mathrm{N})$ doses applied under urea form $\left(450 \mathrm{~g} \mathrm{~N} \mathrm{~kg}^{-1} \mathrm{U}\right)$ $\left(0,75,150\right.$, and $\left.225 \mathrm{~kg} \mathrm{~N} \mathrm{ha}^{-1}\right)$ on system's winter phase. After corn harvesting, the pasture sowing was carried out on May 20, 2008, with $17 \mathrm{~cm}$ among rows. The fertilization occurred at the pasture sowing time with $0.0 \mathrm{~N}, 60 \mathrm{P}_{2} \mathrm{O}_{5}$, and $60 \mathrm{~K}_{2} \mathrm{O} \mathrm{kg} \mathrm{ha}{ }^{-1}$, according to Comissão de Fertilidade do Solo (Comission of Soil Fertility) (1995).

The grazing occurred during 158 days, from July 22 to November 18, 2008; 72 weaned lambs were used for testing. Lamb breeds from Texel and Ile de France were used and their crossbreeds also, and they started grazing at nearly two months old and with initial live weight of $24.7 \mathrm{~kg} \pm 0.57 \mathrm{~kg}$.

The animals were randomly divided into 12 lots of six lambs in the plots and kept under continuous grazing system with ryegrass. The load was variable to keep the pasture at 14 and $15 \mathrm{~cm}$ height (MOOT; LUCAS, 1952) according to Freitas (2003). Stocking adjustment was periodically made at three days intervals considering the ratio between height and mass forage according to Carvalho, Ribeiro Filho, and Poli (2001).

The stocking rate was obtained by the sum of the average weight of the testing animals and the average weight of the regulator animals multiplied by the number of days that they remained into experimental unit. The obtained value was divided by the number of grazing days and expressed in kilogram of live weight per hectare $\left(\mathrm{kg} \mathrm{Lw}^{-1}\right)$. After removing the animals, the pasture desiccation was carried out on December, 2008; then, beans were sown under no-tillage system with $40 \mathrm{~cm}$ among rows and 15 seeds density per linear meter.
Bean emergency occurred on December 15, 2008. The FTS Sovereign bean which belongs to the black trade group was the used bean genotype with indeterminate growth habit, upright, and medium blooming cycle. It is adapted to the mechanical harvesting and it is also moderately resistant to major crop diseases.

The bean crop was fertilized with $100 \mathrm{~kg} \mathrm{P}_{2} \mathrm{O}_{5} \mathrm{ha}^{-1}$ (triple superphosphate) and topdressing with $190 \mathrm{~kg}$ $\mathrm{K}_{2} \mathrm{O}$ ha $^{-1}$ (potassium chloride). Nitrogen was not applied. Control of weeds, pests, and diseases during the crop cycle was carried out according to Araújo et al. (1996).

The bean yield was determined in a $3.2 \mathrm{~m}^{2}$ area ( 2 rows x $0.4 \mathrm{~m} \mathrm{x} 4 \mathrm{~m}$ ); after moisture correction to $13 \%$ and the value was converted to $\mathrm{kg} \mathrm{ha}^{-1}$. The bean was harvested on March 30, 2009.

Samples were taken at 0-5, 5-10, and $10-15 \mathrm{~cm}$ deeps with two replicates for evaluating soil physical attributes. Samplings were taking at the following periods: (a) after corn sowing (2008); (b) after winter phase (2008); and (c) after beans harvesting (2009). Soil bulk density (BD) was determined by the volumetric ring method, while total porosity, macroporosity, and microporosity were determined by the voltage table method (EMBRAPA, 1997).

Results presented homogeneous variances by Lilliefors test and were submitted to analysis of variance by $\mathrm{F}$ test. When the results differ at $5 \%$, the averages of qualitative factor (grazing/no grazing) were compared by Tukey test, and quantitative factor (nitrogen) was compared by regression analysis with SISVAR software (FERREIRA, 2000).

\section{RESULTS AND DISCUSSION}

There was no interaction ( $\mathrm{p}>0.05)$ among factors evaluated on physical soil attributes. It was observed that BD values (Table 3 ) did not reach limiting values 
Table 3 - Bulk density $\left(\mathrm{Mg} \mathrm{m}^{-3}\right)$ on 0-5, 5-10 and 10-15 $\mathrm{cm}$ layers in three sampling periods with and without grazing, Guarapuava, PR

\begin{tabular}{|c|c|c|c|c|c|c|}
\hline \multirow{4}{*}{$\mathrm{N}$ doses $\left(\mathrm{kg} \mathrm{ha}^{-1}\right)$} & \multicolumn{2}{|c|}{ After corn harvesting } & \multirow{2}{*}{\multicolumn{2}{|c|}{ After grazing }} & \multicolumn{2}{|c|}{ After beans harvesting } \\
\hline & \multicolumn{4}{|c|}{$0-5 \mathrm{~cm}$ layer } & & \\
\hline & \multicolumn{2}{|c|}{ Management system } & \multicolumn{2}{|c|}{ Management system } & \multicolumn{2}{|c|}{ Management system } \\
\hline & with grazing & without grazing & with grazing & without grazing & with grazing & without grazing \\
\hline 0 & 0.89 & 0.99 & 1.07 & 1.01 & 1.00 & 0.96 \\
\hline 75 & 0.95 & 0.87 & 1.10 & 0.98 & 1.01 & 1.03 \\
\hline 150 & 0.96 & 0.97 & 1.05 & 1.05 & 0.95 & 1.00 \\
\hline 225 & 1.30 & 0.92 & 1.10 & 1.00 & 0.94 & 1.02 \\
\hline \multirow[t]{4}{*}{ Mean } & 0.96 & 0.94 & $1.08 \mathrm{a}$ & $1.01 \mathrm{~b}$ & 0.97 & 1.00 \\
\hline & \multicolumn{2}{|c|}{ General average $=0.95$} & \multicolumn{2}{|c|}{ General average $=1.04$} & \multicolumn{2}{|c|}{ General average $=0.98$} \\
\hline & \multicolumn{2}{|c|}{$\mathrm{CV}(\%)=6.12$} & \multicolumn{2}{|c|}{$\mathrm{CV}(\%)=6.52$} & \multicolumn{2}{|c|}{$\mathrm{CV}(\%)=5.39$} \\
\hline & \multicolumn{6}{|c|}{$5-10 \mathrm{~cm}$ layer } \\
\hline 0 & 1.02 & 1.03 & 1.03 & 1.02 & 0.98 & 1.07 \\
\hline 75 & 0.99 & 0.97 & 1.09 & 1.01 & 1.05 & 1.06 \\
\hline 150 & 0.84 & 0.91 & 1.15 & 1.00 & 0.95 & 0.91 \\
\hline 225 & 1.07 & 1.02 & $1.18 \mathrm{a}$ & $0.97 \mathrm{~b}$ & 0.97 & 1.06 \\
\hline \multirow[t]{3}{*}{ Mean } & 0.98 & 0.98 & $1.11 \mathrm{a}$ & $0.99 \mathrm{~b}$ & 0.98 & 1.02 \\
\hline & \multicolumn{2}{|c|}{ General average $=0.98$} & \multicolumn{2}{|c|}{ General average $=1.05$} & \multicolumn{2}{|c|}{ General average $=1.01$} \\
\hline & \multicolumn{2}{|c|}{$\mathrm{CV}(\%)=16.32$} & \multicolumn{2}{|c|}{$\mathrm{CV}(\%)=7.33$} & \multicolumn{2}{|c|}{$\mathrm{CV}(\%)=9.47$} \\
\hline \multicolumn{7}{|c|}{$10-15 \mathrm{~cm}$ layer } \\
\hline 0 & 1.02 & 0.89 & 1.06 & 0.99 & 1.08 & 1.12 \\
\hline 75 & 0.97 & 1.02 & 1.13 & 1.04 & 1.03 & 1.03 \\
\hline 150 & 1.05 & 0.98 & 1.07 & 1.12 & 1.04 & 1.01 \\
\hline 225 & 1.02 & 1.02 & 1.02 & 1.13 & 1.00 & 1.05 \\
\hline \multirow[t]{3}{*}{ Mean } & 1.01 & 0.99 & 1.06 & 1.07 & 1.04 & 1.05 \\
\hline & \multicolumn{2}{|c|}{ General average $=1.00$} & \multicolumn{2}{|c|}{ General average $=1.07$} & \multicolumn{2}{|c|}{ General average $=1.05$} \\
\hline & \multicolumn{2}{|c|}{$\mathrm{CV}(\%)=8.12$} & \multicolumn{2}{|c|}{$\mathrm{CV}(\%)=5.80$} & \multicolumn{2}{|c|}{$\mathrm{CV}(\%)=6.31$} \\
\hline
\end{tabular}

Mean in the same column and layer does not differ by $F$ test $(p>0.05)$

(1.25 to $1.3 \mathrm{Mg} \mathrm{m}^{-3}$ ) to plants' development and growth according to Reinert et al. (2008) and Reichert et al. (2009). However, it is remarkable that the BD value increased after grazing and such value decreased at all nitrogen doses after beans harvesting, indicating that there are no significantly changes on soil physical attributes when ICLS are carried out with no-tillage and moderate grazing stocking.

Costa etal.(2009) and Flores et al.(2007) evaluated animals' grazing as well as different management on soil physical attributes and reported similar results. The low BD was attributed to high aggregate stability and to soil structure preservation, which had been used with grazing in winter for eight years before this trial. It also indicates that controlled grazing during the winter does not affect soil physical quality (SILVA et al., 2011; COSTA et $a l ., 2009$ ) and demystifies that the animals' presence in farming areas causes problems to the subsequent crop. Stocking rate was 498, 1.014, 953 and $1.208 \mathrm{~kg} \mathrm{Lw}^{-1}$ on average, for respective treatments with $0,75,150$, and $225 \mathrm{~kg} \mathrm{~N} \mathrm{ha}^{-1}$.

Regarding macroporosity (Table 4), there was similar trend of BD, with a decrease on values after animals' grazing on the surface layer; those values increased at all nitrogen doses after bean cropping. Macroporosity was higher in areas without grazing after winter period. Flores et al. (2007) observed similar results. This pattern usually occurs. However, the 
Table 4 - Macroporosity $\left(\mathrm{m}^{3} \mathrm{~m}^{-3}\right)$ in 0-5, 5-10 and 10-15 $\mathrm{cm}$ layers in three sampling periods with and without grazing, Guarapuava, PR

\begin{tabular}{|c|c|c|c|c|c|c|}
\hline \multirow{4}{*}{$\mathrm{N}$ doses $\left(\mathrm{kg} \mathrm{ha}^{-1}\right)$} & \multicolumn{2}{|c|}{ After corn harvesting } & \multirow{2}{*}{\multicolumn{2}{|c|}{$\frac{\text { After grazing }}{0-5 \mathrm{~cm} \text { layer }}$}} & \multicolumn{2}{|c|}{ After beans harvesting } \\
\hline & & & & & & \\
\hline & \multicolumn{2}{|c|}{ Management system } & \multicolumn{2}{|c|}{ Management system } & \multicolumn{2}{|c|}{ Management system } \\
\hline & With grazing & Without grazing & With grazing & Without grazing & With grazing & Without grazing \\
\hline 0 & 0.20 & 0.18 & 0.13 & 0.19 & 0.19 & 0.16 \\
\hline 75 & 0.18 & 0.19 & $0.15 \mathrm{~b}$ & $0.23 \mathrm{a}$ & 0.18 & 0.18 \\
\hline 150 & 0.21 & 0.16 & 0.13 & 0.19 & 0.19 & 0.17 \\
\hline 225 & 0.21 & 0.15 & 0.13 & 0.20 & 0.16 & 0.17 \\
\hline \multirow[t]{4}{*}{ Mean } & 0.20 & 0.17 & $0.13 \mathrm{~b}$ & $0.20 \mathrm{a}$ & 0.18 & 0.17 \\
\hline & \multicolumn{2}{|c|}{ General average $=0.19$} & \multicolumn{2}{|c|}{ General average $=0.17$} & \multicolumn{2}{|c|}{ General average $=0.18$} \\
\hline & \multicolumn{2}{|c|}{$\mathrm{CV}(\%)=16.64$} & \multicolumn{2}{|c|}{$\mathrm{CV}(\%)=24.34$} & \multicolumn{2}{|c|}{$\mathrm{CV}(\%)=14.11$} \\
\hline & \multicolumn{6}{|c|}{$5-10 \mathrm{~cm}$ layer } \\
\hline 0 & 0.17 & 0.17 & 0.17 & 0.19 & 0.16 & 0.16 \\
\hline 75 & 0.17 & 0.18 & 0.17 & 0.23 & 0.18 & 0.15 \\
\hline 150 & 0.16 & 0.17 & 0.17 & 0.18 & 0.17 & 0.19 \\
\hline 225 & 0.17 & 0.17 & 0.16 & 0.19 & 0.20 & 0.19 \\
\hline \multirow[t]{4}{*}{ Mean } & 0.17 & 0.17 & $0.17 \mathrm{~b}$ & $0.19 \mathrm{a}$ & 0.18 & 0.17 \\
\hline & \multicolumn{2}{|c|}{ General average $=0.17$} & \multicolumn{2}{|c|}{ General average $=0.18$} & \multicolumn{2}{|c|}{ General average $=0.18$} \\
\hline & \multicolumn{2}{|c|}{$\mathrm{CV}(\%)=6.87$} & \multicolumn{2}{|c|}{$\mathrm{CV}(\%)=12.87$} & \multicolumn{2}{|c|}{$\mathrm{CV}(\%)=9.10$} \\
\hline & \multicolumn{6}{|c|}{$10-15 \mathrm{~cm}$ layer } \\
\hline 0 & 0.19 & 0.21 & 0.19 & 0.21 & 0.18 & 0.14 \\
\hline 75 & 0.16 & 0.18 & 0.16 & 0.18 & 0.17 & 0.14 \\
\hline 150 & 0.15 & 0.15 & 0.15 & 0.15 & 0.17 & 0.17 \\
\hline 225 & 0.15 & 0.17 & 0.15 & 0.17 & 0.18 & 0.18 \\
\hline \multirow[t]{3}{*}{ Mean } & 0.16 & 0.18 & 0.16 & 0.18 & 0.18 & 0.16 \\
\hline & \multicolumn{2}{|c|}{ General average $=0.17$} & \multicolumn{2}{|c|}{ General average $=0.18$} & \multicolumn{2}{|c|}{ General average $=0.16$} \\
\hline & \multicolumn{2}{|c|}{$\mathrm{CV}(\%)=3.93$} & \multicolumn{2}{|c|}{$\mathrm{CV}(\%)=16.38$} & \multicolumn{2}{|c|}{$\mathrm{CV}(\%)=12.89$} \\
\hline
\end{tabular}

"Mean in the same column and layer does not differ by $\mathrm{F}$ test $(\mathrm{p}>0.05)$

reduction of macropores amount in grazed areas is not enough to affect plants' development (ANDREOLLA, 2010; CARASSAI et al., 2011).

Regarding microporosity (Table 5), it was found out that there was insignificant increase in value after animals' grazing. Changes in soil microporosity observed on ICLS under no-tillage with moderate grazing (SPERA et al., 2009; FLORES et al., 2008) are generally small in magnitude and did not reach critical levels for root growing of cultivated plants.

This behavior was expected and was due to radicular renewal ability and biopores' formation, which promoted the soil decompaction by using forage plants in ICLS. Castagnara et al. (2012) and Balbinot JR. et al. (2009) also studied different soil managements and did not find out any significant differences on macroporosity between areas with or without grazing.

Regarding total porosity, there were no differences among treatments. Thus, it can be concluded that a well-structured management system affects directly soil response as well as its physical, chemical, and biological properties.

Soil under cropping for a certain period can recover its initial conditions concerning the physical attributes and it can prove that animals' grazing presence does not affect soil quality when rationally used. Loss et al. (2012) and 
Table 5 - Microporosity $\left(\mathrm{m}^{3} \mathrm{~m}^{-3}\right)$ in 0-5, 5-10 and 10-15 $\mathrm{cm}$ layers in three sampling periods with and without grazing, Guarapuava, PR

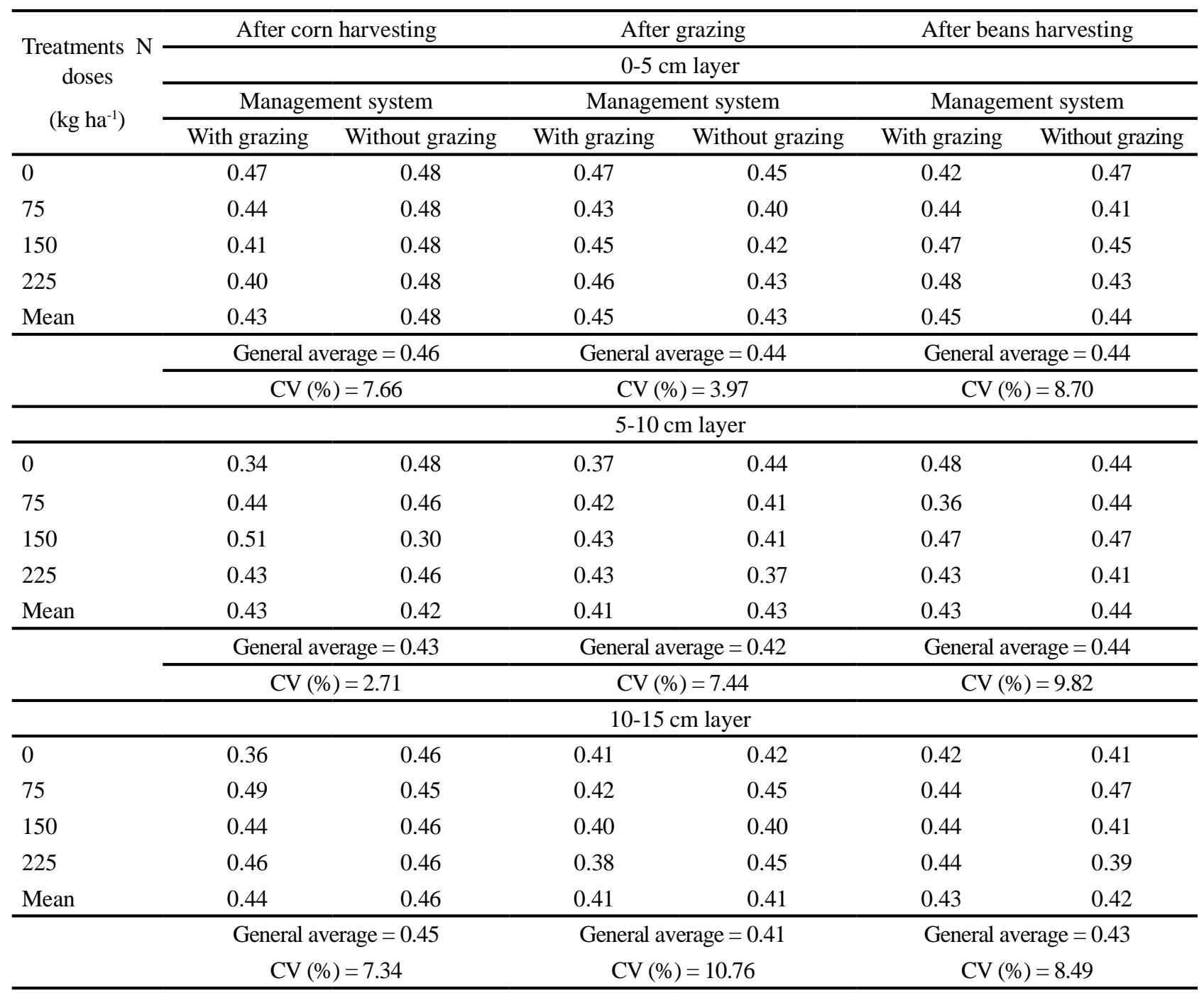

"Mean in the same column and layer does not differ by $\mathrm{F}$ test $(\mathrm{p}>0.05)$

Table 6 - Total porosity $\left(\mathrm{m}^{3} \mathrm{~m}^{-3}\right)$ in $0-5,5-10$ and $10-15 \mathrm{~cm}$ layers in three sampling periods with and without grazing, Guarapuava, PR

\begin{tabular}{|c|c|c|c|c|c|c|}
\hline \multirow{4}{*}{$\begin{array}{c}\mathrm{N} \text { doses } \\
\left(\mathrm{kg} \mathrm{ha}^{-1}\right)\end{array}$} & \multicolumn{2}{|c|}{ After corn harvesting } & \multicolumn{2}{|c|}{ After grazing } & \multicolumn{2}{|c|}{ After beans harvesting } \\
\hline & \multicolumn{6}{|c|}{$0-5 \mathrm{~cm}$ layer } \\
\hline & \multicolumn{2}{|c|}{ Management system } & \multicolumn{2}{|c|}{ Management system } & \multicolumn{2}{|c|}{ Management system } \\
\hline & With grazing & Without grazing & With grazing & Without grazing & With grazing & Without grazing \\
\hline 0 & 0.67 & 0.66 & 0.61 & 0.64 & 0.60 & 0.63 \\
\hline 75 & 0.63 & 0.67 & 0.58 & 0.63 & 0.62 & 0.29 \\
\hline 150 & 0.68 & 0.63 & 0.58 & 0.61 & 0.66 & 0.63 \\
\hline 225 & 0.62 & 0.62 & 0.59 & 0.63 & 0.64 & 0.63 \\
\hline \multirow[t]{3}{*}{ Mean } & 0.63 & 0.65 & 0.59 & 0.63 & 0.63 & 0.62 \\
\hline & \multicolumn{2}{|c|}{ General average $=0.64$} & \multicolumn{2}{|c|}{ General average $=0.61$} & \multicolumn{2}{|c|}{ General average $=0.63$} \\
\hline & \multicolumn{2}{|c|}{$\mathrm{CV}(\%)=3.32$} & \multicolumn{2}{|c|}{$\mathrm{CV}(\%)=3.97$} & \multicolumn{2}{|c|}{$\mathrm{CV}(\%)=4.27$} \\
\hline
\end{tabular}


Table 6 Continued

\begin{tabular}{|c|c|c|c|c|c|c|}
\hline & \multicolumn{6}{|c|}{$5-10 \mathrm{~cm}$ layer } \\
\hline 0 & 0.62 & 0.64 & 0.58 & 0.60 & 0.64 & 0.59 \\
\hline 75 & 0.61 & 0.63 & 0.59 & 0.64 & 0.55 & 0.59 \\
\hline 150 & 0.67 & 0.67 & 0.57 & 0.61 & 0.66 & 0.66 \\
\hline 225 & 0.60 & 0.63 & $0.54 \mathrm{~b}$ & $0.63 \mathrm{a}$ & 0.62 & 0.60 \\
\hline \multirow[t]{4}{*}{ Mean } & 0.63 & 0.65 & $0.59 \mathrm{~b}$ & $0.63 \mathrm{a}$ & 0.63 & 0.62 \\
\hline & \multicolumn{2}{|c|}{ General average $=0.64$} & \multicolumn{2}{|c|}{ General average $=0.60$} & \multicolumn{2}{|c|}{ General average $=0.62$} \\
\hline & \multicolumn{2}{|c|}{$\mathrm{CV}(\%)=18.13$} & \multicolumn{2}{|c|}{$\mathrm{CV}(\%)=3.85$} & \multicolumn{2}{|c|}{$\mathrm{CV}(\%)=7.16$} \\
\hline & \multicolumn{6}{|c|}{$10-15 \mathrm{~cm}$ layer } \\
\hline 0 & 0.56 & 0.67 & $0.55 \mathrm{~b}$ & $0.63 \mathrm{a}$ & 0.60 & 0.56 \\
\hline 75 & 0.65 & 0.63 & 0.59 & 0.61 & 0.61 & 0.61 \\
\hline 150 & 0.59 & 0.63 & 0.60 & 0.59 & 0.62 & 0.59 \\
\hline 225 & 0.60 & 0.62 & $0.62 \mathrm{a}$ & $0.54 \mathrm{~b}$ & 0.59 & 0.70 \\
\hline \multirow[t]{3}{*}{ Mean } & 0.63 & 0.65 & $0.59 \mathrm{a}$ & $0.59 \mathrm{a}$ & 0.63 & 0.62 \\
\hline & \multicolumn{2}{|c|}{ General average $=0.64$} & \multicolumn{2}{|c|}{ General average $=0.60$} & \multicolumn{2}{|c|}{ General average $=0.62$} \\
\hline & \multicolumn{2}{|c|}{$\mathrm{CV}(\%)=3.50$} & \multicolumn{2}{|c|}{$\mathrm{CV}(\%)=7.34$} & \multicolumn{2}{|c|}{$\mathrm{CV}(\%)=10.62$} \\
\hline
\end{tabular}

${ }^{*}$ Mean in the same column and layer does not differ by $\mathrm{F}$ test $(\mathrm{p}>0.05)$

Lanzanova et al. (2010) evaluated different management systems regarding soil density and fertility and found out that forage and crop association on ICLS showed lower soil density, higher fertility, and increased soil nutrients content (compared to monoculture systems), which are extremely important to keep available environment for subsequent crop.

It was observed an increase in bean grain yield (Figure 1) when higher nitrogen doses were applied as topdressing fertilization at the previous winter pasture.

Figure 1 - Bean's yield $\left(\mathrm{kg} \mathrm{ha}^{-1}\right)$ for each nitrogen dose in the crop according to the nitrogen applied in black oat and ryegrass in Guarapuava (PR), 2009

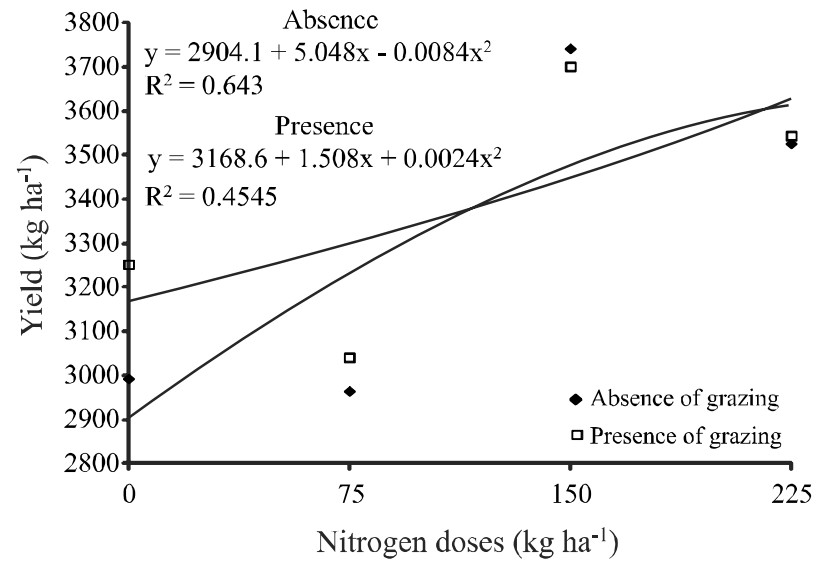

Bean yield did not differ between grazing presence (3.385,5 kg ha-1) and grazing absence $\left(3.307,5 \mathrm{~kg} \mathrm{ha}^{-1}\right)$ areas ( $>0,05)$; however, in comparison to mean bean yield of Paraná, values were significantly higher (1.528 $\mathrm{kg} \mathrm{ha}^{-1}$ ) (SALVADOR, 2012) indicating that ICLS were successfully used to maintain soil physical structure and bean productivity.

\section{CONCLUSIONS}

1. When ICLS were managed with no-tillage and moderate grazing, sheep trampling did not affect negatively soil physical attributes which did not reach critical levels for subsequent bean crop;

2. Summer bean grain yield was not affected by previous animal presence on winter pasture;

3. In no-tillage, ICLS with moderate grazing, nitrogen fertilization on winter ryegrass/oat culture with pasture ensure high bean yield on summer without requiring nitrogen reapplication; $150 \mathrm{~kg} \mathrm{ha}^{-1}$ of nitrogen is recommended to system's winter pasture phase.

\section{REFERENCES}

ANDREOLLA, V. R. M. Integração lavoura-pecuária em Latossolo Brunocom pastagem de inverno, doses de nitrogênio e pastejo - atributos físicos do solo e rendimento das culturas 
de milho e feijoeiro/2010.135 f. (Tese de doutorado) Doutorado em Agronomia - Produção Vegetal - Universidade Federal do Paraná. Curitiba, Paraná. 2010.

ARAÚJO, R. S. et al. Cultura do feijoeiro comum no Brasil. Piracicaba: Potafos, 1996. 786 p.

BALBINOT JUNIOR, A. A. et al. Desempenho da cultura do feijão após diferentes formas de uso do solo no inverno. Ciência Rural, Santa Maria, v. 39, n. 8, p. 2340-2346, 2009.

CARVALHO, P. C. F.; RIBEIRO FILHO, H. M. N.; POLI, C. H. E. C. Importância da estrutura da pastagem na ingestão e seleção de dietas pelo animal em pastejo. In: PEDREIRA, C. G. S e DA SILVA, S. C. (Ed) A Produção Animal na Visão dos Brasileiros, Piracicaba: FEALQ, p. 853-871, 2001.

CARASSAI, I. J. et al. Atributos físicos do solo sob intensidades de pastejo e métodos de pastoreio com cordeiros em integração lavoura-pecuária. Pesquisa agropecuária brasileira, v. 46, n. 10, p. 1284-1290, 2011.

CASTAGNARA, D. D. et al. Atributos físicos de Latossolo Vermelho sob pousio ou cultivado com forrageiras tropicais sob pastejo. Biosciense Journal, v. 28, p. 150-158, 2012.

CARVAlHO, J. L. N. et al. Potencial de sequestro de carbono em diferentes biomas do Brasil. Revista Brasileira de Ciência do Solo, v. 34, p. 277-289, 2010.

CONTE, O. et al. Evolução de atributos físicos de solo em sistema de integração lavoura-pecuária. Pesquisa Agropecuária Brasileira, v. 46, p. 1301-1309, 2011.

COMISSÃO DE FERTILIDADE DO SOLO - RS/SC (Passo Fundo, RS). Recomendações de adubação e calagem para os Estados do Rio Grande do Sul e Santa Catarina. 3. ed. Passo Fundo: Sociedade Brasileira de Ciência do Solo/ Embrapa-CNPT, 1995. 223 p.

COSTA, A. et al. Propriedades físicas do solo em sistemas de manejo na integração agricultura-pecuária. Revista Brasileira de Ciência do Solo, vol. 33, n. 2, p. 235-244, 2009.

EMPRESA BRASILEIRA DE PESQUISA AGROPECUÁRIA. Centro Nacional de Pesquisa de Solos. Manual de análise de solo. 2. ed. rev. atual. Rio de Janeiro: Centro Nacional de Pesquisa de Solos, 1997. 212 p.

EMPRESA BRASILEIRA DE PESQUISA AGROPECUÁRIA. Sistema brasileiro de classificação de solo. Humberto Gonçalves dos Santos, 3 ed. Rio de Janeiro: Centro Nacional de Pesquisa de Solos, 2013. 353 p.

FERREIRA, D. F. Manual do sistema Sisvar para análises estatísticas. Lavras: UFLA, 2000. 63 p.

FLORES, J. P. C. et al. Atributos físicos do solo e rendimento de soja em sistema plantio direto em integração lavourapecuária com diferentes pressões de pastejo. Revista Brasileira de Ciência do Solo, v. 31, p. 771-780, 2007.

FLORES, J. P. C. et al. Atributos químicos do solo em função da aplicação superficial de calcário em sistema de integração lavoura-pecuária submetido a pressões de pastejo em plantio direto. Revista Brasileira de Ciência do Solo, v. 32, p. 23852396, 2008.

FREITAS, T. M. S. de. Dinâmica da produção de forragem, comportamento ingestivo e produção de ovelhas Ile de France em pastagem de azevém anual (Lolium multiflorum Lam.) em resposta a doses de nitrogênio/2003. 114f. (Dissertação de Mestrado) Mestrado em Zootecnia - Faculdade de Agronomia, Universidade Federal do Rio Grande do Sul, Porto Alegre. 2003.

GiARolA, N. F. B.; TORMENA, C. A.; DUTRA, A. C. Degradação física de um Latossolo Vermelho utilizado para produção intensiva de forragem. Revista Brasileira de Ciência do Solo, v. 31, p. 863-873, 2007.

INSTITUTO AGRONÔMICO DO PARANÁ - IAPAR. Cartas climáticas do estado do Paraná, 1994. Londrina: IAPAR, 1994. 49 p.

LANZANOVA, M. E. et al. Atributos físicos de um Argissolo em sistemas de culturas de longa duração sob semeadura direta. Revista Brasileira de Ciência do Solo, v. 34, p. 13331342,2010

LANZANOVA, M. E. et al. Atributos Físicos do Solo em Sistema de Integração Lavoura-Pecuária sob Plantio Direto. Revista Brasileira Ciência do Solo, v. 31, p. 1131-1140, 2007.

LOSS, A. et al. Densidade e fertilidade do solo sob sistemas de plantio direto e de integração lavoura-pecuária no Cerrado. Revista Ciência Agraria, v. 55, n. 4, p. 260-268, 2012.

MAAK, R. Geografia física do Estado do Paraná. Banco de Desenvolvimento do Estado do Paraná. Curitiba: UFPR / IBPT. $1968.350 \mathrm{p}$.

MACEDO, M. C. M. Integração lavoura e pecuária: o estado da arte e inovações tecnológicas. Revista Brasileira de Zootecnia, v. 38, p. 133-146, 2009

MOOT, G. O; LUCAS, H. L. The design conduct and interpretation of grazing trials on cultivated and improved pastures. In: INTERNATIONAL GRASSLAND CONGRESS. 6. Proceedings Pensylvania: State College, 1952, p. 1380-1395.

REICHERT, J. M. et al. Reference bulk density and critical degree of compactness for no-till crop, production in subtropical highly weathered soils. Soil \& Tillage Research, v. 102 , n. 2 , p. $242-254,2009$

REICHERT, P. Cultura do feijão e nitrogênio no sistema de integração lavoura-pecuária. 2012. 54 f. (Dissertação de Mestrado) Mestrado em Agronomia - Universidade Estadual do Centro-Oeste, Guarapuava-PR, 2012.

REINERT, D. J. et al. Limites críticos de densidade do solo para o crescimento de raízes de plantas de cobertura em Argissolo Vermelho. Revista Brasileira de Ciência do Solo, v. 32, n. 5, p. 1805-1816, 2008.

SALVADOR, C. A. Feijão - Análise e Conjuntura. SEAB - Secretaria de Estado da Agricultura e do Abastecimento. Departamento de Economia Rural, 2012. Disponível em: www.agricultura.pr.gov.br/arquivos/File/federal/.../feijao_ 2012_13.pdf;. Acesso em: 01/07/2014. 
SILVA, R. F. da et al. Análise conjunta de atributos físicos e biológicos do solo sob sistema de integração lavourapecuária. Pesquisa Agropecuária Brasileira, v. 46, n. 10, p. 1277-1283, 2011.
SPERA, S. T. et al. Integração lavoura e pecuária e os atributos físicos de solo manejado sob sistema plantio direto. Revista Brasileira de Ciência do Solo, v. 33, n. 1, p. 129136, 2009. 